\title{
Optimized chloroquine phosphate dosage regimens for early virological clearance of severe acute respiratory syndrome coronavirus 2 using Monte Carlo simulation
}

\author{
Nattapong Tidwong1, \\ Baralee Punyawudho ${ }^{1}$, \\ Pannee Leelawattanachai ${ }^{2}$, \\ Suwida Tangtrakultham ${ }^{3}$, \\ Pitchaya Dilokpattanamongkol ${ }^{3}$, \\ Taniya Paiboonvong4, \\ Supatat Chumnumwat ${ }^{3}$, \\ Preecha Montakantikul $3^{*}$ \\ 1 Department of Pharmaceutical Care, \\ Faculty of Pharmacy, Chiang Mai University, \\ Chiang Mai, Thailand \\ 2 Department of Pharmacy, Faculty of \\ Medicine Vajira Hospital, Navamindradhiraj \\ University, Bangkok, Thailand \\ 3 Department of Pharmacy, Faculty of \\ Pharmacy, Mahidol University, Bangkok, \\ Thailand \\ ${ }^{4}$ Department of Pharmacy Practice, College \\ of Pharmacy, Rangsit University, Pathum \\ Thani, Thailand
}

\section{*Corresponding author:}

Preecha Montakantikul

preecha.mon@mahidol.ac.th

Keywords:

Chloroquine; Monte Carlo;

Pharmacokinetics; SARS-CoV-2; COVID-19 https://www.pharmacy.mahidol.ac.th/journal/ (๑) Faculty of Pharmacy, Mahidol University (Thailand) 2021

\begin{abstract}
Chloroquine (CQ) exhibited promising in vitro activity against severe acute respiratory syndrome coronavirus 2 (SARS-CoV-2), but the optimal dosage regimens remain unknown. Our objective was to explore the optimal chloroquine phosphate (CQP) dosage regimens for early achievement of virological clearance within 48-72 hours to diminish in-hospital transmission to front-line healthcare workers. A 10,000-subject Monte Carlo simulation was performed to calculate both probability of efficacy and safety attainment (PTA) using pharmacokinetic (PK) parameters obtained from the published population PK study. Dosage regimens that early achieved PTA of efficacy $\left(\mathrm{PTA}_{\text {eff }}\right) \geq 90 \%$ within $48-72$ hours, while maintained PTA of toxicity $\left(\mathrm{PTA}_{\text {tox }}\right) \leq 1 \%$ were considered optimal. For the previously proposed regimens in published guidelines and clinical studies, all dosage regimens could not achieve $\geq 90 \% \mathrm{PTA}_{\text {eff, }}$ except one with the highest dosage regimen. Our simulations suggested that large amount of loading dose was required for the early achievement. We designed three dosage regimens containing high loading dose (2-3 gram per day), which early achieved $\geq 90 \% \mathrm{PTA}_{\text {eff }}$ within 48-72 hours, while also maintained $\leq 1 \% \mathrm{PTA}_{\text {tox }}$ throughout the treatment course. Further clinical studies are needed to prove the efficacy and safety of our designed regimens.
\end{abstract}

\section{INTRODUCTION}

Coronavirus disease 2019 (COVID-19) firstly emerged in December 2019 and has spread rapidly all over the world .The rapidly increasing number of cases compelled the World Health Organization (WHO) to officially declare COVID-19 as a global pandemic in March 20201. Remdesivir is one of the broad-spectrum antivirals that have been recommended as an antiviral treatment in several published guidelines ${ }^{2-4}$ because of its promising in vitro ${ }^{5}$ and clinical effectiveness ${ }^{6,7}$. Nonetheless, it is not globally available, particularly in developing countries, and its supply is also limited . Chloroquine (CQ), a wildly available antimalarial, has also been proposed as another appealing antiviral for COVID-19 treatment .It exhibited impressive in vitro activity ${ }^{5,8,9}$ with comparable half-maximal effective concentration $\left(\mathrm{EC}_{50}\right)$ to remdesivir ${ }^{5}$ and showed possible benefit in improving lung findings and shortening the disease course in a small clinical study ${ }^{10}$. Unfortunately, recent data from clinical studies suggested that hydroxychloroquine (HCQ), a hydroxyl 
analogue of CQ, showed no additional benefit on mortality reduction ${ }^{11-13}$ or improving clinical COVID status ${ }^{14-16}$ to usual care. CQ was consequently revoked from the emergency use authorization (EUA) ${ }^{17}$, and some published guidelines recommended against its use as an antiviral treatment for hospitalized COVID-19 patients except in clinical trial settings ${ }^{3,4}$. However, apart from mortality reduction, HCQ treated COVID-19 patients tend to have more viral negative conversion rate over usual care during the early phase of treatment, although the final 4week conversion rate was equal ${ }^{18}$. Likewise, a clinical study showed that $90 \%$ of CQ treated patients achieved viral negative conversion on the tenth day ${ }^{19}$, highlighting engaging early viral eradication benefit of CQ.

Front-line healthcare workers are at increased risk for SARS-CoV-2 infection ${ }^{20}$. The infection rate among this group was reported as high as $10-20 \%^{21,22}$. In the comprehensive COVID-19 pandemic management, the prevention of nosocomial transmission should therefore be concerned, besides complete cure and mortality reduction. Since high SARS-CoV-2 viral load, which contributed to the high infectivity in cell culture $\operatorname{model}^{23}$, was reported during the early phase of disease ${ }^{24}$, SARS-CoV-2 may easily spread to healthcare workers during early hospital admission. Using CQ to achieve early virological clearance within 48-72 hours can be the option to diminish in-hospital transmission. This early administration may also have additional treatment advantages, albeit uncertain clinical effectiveness. However, the appropriate dosage regimen is currently unknown, and under-dosing may be one factor contributing to ineffectiveness.

Monte Carlo simulation (MCS) is a useful mathematical tool, which has widely been used for designing antibiotic regimens to improve treatment outcomes ${ }^{25,26}$. Our study, therefore, applied MCS to explore the optimal chloroquine phosphate (CQP) dosage regimens, which attain early virological clearance within 48-72 hours while preserving the lowest toxicity.

\section{MATERIALS AND METHODS}

\subsection{Pharmacokinetics model}

A pharmacokinetic (PK) study with MCS was performed using $\mathrm{PK}$ data from the previously published population PK study ${ }^{27}$ (Table 1). Since there was no study in COVID-19, the population PK of CQ in adults with uncomplicated malaria ${ }^{27}$ was used. A set of parameters was randomly generated according to each estimate and interindividual variability of the parameters. Previous data showed that CQ pharmacokinetic fit a two-compartment model with one transit compartment for absorption ${ }^{27}$. This model was used for whole blood concentrationtime profile simulations.

Table 1. Population pharmacokinetic parameters of CQ used in Monte Carlo simulation ${ }^{27}$.

\begin{tabular}{lcc}
\hline Parameters $^{\mathbf{a}}$ & Estimates & IIV $^{\mathbf{b}}$ \\
\hline $\mathrm{K}_{\mathrm{a}}\left(\mathrm{h}^{-1}\right)$ & 2.0986 & - \\
$\mathrm{CL} / \mathrm{F}(\mathrm{L} / \mathrm{h})$ & 6.13 & - \\
$\mathrm{V} \mathrm{C} / \mathrm{F}(\mathrm{L})$ & 468.00 & - \\
$\mathrm{V} / \mathrm{F}(\mathrm{L})$ & 1600.00 & 20 \\
$\mathrm{Q} / \mathrm{F}(\mathrm{L} / \mathrm{h})$ & 37.70 & - \\
\hline
\end{tabular}

${ }^{a} K_{a}$ is calculated from $n+1 / M T T,{ }^{b}$ Values expressed as coefficient variation (CV; \%). CQ; chloroquine, IIV; interindividual variability, $K_{a}$; absorption rate constant, $F$; bioavailability, $C L / F$; total clearance, $V_{C} / F$; volume of distribution for central compartment, $V_{P} / F$; volume of distribution for peripheral compartment, $Q / F$; intercompartmental clearance, $n$; number of transit compartment, MTT; mean transit time. The ratio of metabolic clearance from CQ to desethylchloroquine to total clearance was fixed at 0.176 . The $F$ was fixed at 1 .

\subsection{Pharmacodynamics model}

CQ exhibited promising in vitro activity against SARS-CoV-2 with low $\mathrm{EC}_{50}{ }^{5,8,9}$, but there was no study reported a correlation between $\mathrm{EC}_{50}$ and CQ concentration in human. Therefore, we simulated the minimum efficacious concentration based on the clinical study in COVID-19. According to the clinical study by Huang et al. ${ }^{19}, 90 \%$ of overdose suggested that whole blood concentration above $13 \mu \mathrm{mol} / \mathrm{L}$ ( $95 \%$ credible interval (CI) 10 to 16) was associated with greater than $1 \%$ mortality ${ }^{28}$.
COVID-19 patients who were given CQP $500 \mathrm{mg}$ twice daily for 10 days had negative real-time polymerase chain reaction (RT-PCR) conversion on the tenth day. We simulated whole blood trough concentration $\left(\mathrm{C}_{\text {trough }}\right)$ on the tenth day of a $90^{\text {th }}$ percentile virtual subject, $4.98 \mu \mathrm{mol} / \mathrm{L}$, as an indicator for efficacy. Considering safety limit, pharmacokinetic-pharmacodynamic (PK/PD) model based on pooled data of acute intentional CQ These data were consistent with retrospective data from chronic CQ usage, which $80 \%$ of patients with whole blood concentration above $10 \pm 1.25$ 
$\mu \mathrm{mol} / \mathrm{L}$ reported adverse events ${ }^{29}$. Assuring the safety, we used the lowest reported adverse level, $10 \mu \mathrm{mol} / \mathrm{L}$, as an indicator for the toxicity. This toxicity cut-point were also used in several published PK modelings of CQ in COVID-19 $9^{30,31}$.

\subsection{Monte Carlo simulation (MCS)}

A 10,000-subject MCS was performed using Crystal Ball 2017 (Decisioneering Inc., Denver, CO USA) .Log-normal distributions were evaluated for between-patient variability. Based on CQ linear pharmacokinetic behavior ${ }^{32,33}$, the probability of target attainment (PTA) was calculated as the percentage of all 10,000 estimates that achieve a pre-defined clinical target. Simulations were conducted for the previously proposed regimens in published guidelines $^{34-38}$, regimen used in clinical studies ${ }^{10,19,39}$, and our designed regimens (Table 2), to evaluate both PTA of efficacy and toxicity. Dosage regimens that achieved the PTA of efficacy $\left(\right.$ PTA $\left._{\text {eff }}\right) \geq 90 \%$ within the first 48-72 hours with the total lowest dose, while maintaining the PTA of toxicity $\left(\mathrm{PTA}_{\text {tox }}\right) \leq 1 \%$ were considered optimal.

Table 2. Chloroquine phosphate (CQP) dosage regimen for simulation ${ }^{10,19,34-39}$.

\begin{tabular}{|c|c|}
\hline Dosage regimens & Recommended guidelines or clinical studies \\
\hline $500 \mathrm{mg} \mathrm{q} 12 \mathrm{~h}$ for 5 days & $\begin{array}{l}\text { Multicenter collaboration group of the department of sciences and } \\
\text { technology and Health commission of Guangdong province } \\
\text { Thai department of disease control }\end{array}$ \\
\hline $500 \mathrm{mg} \mathrm{q} 12 \mathrm{~h}$ for 7 days & $\begin{array}{l}\text { National health commission and state of administration of traditional } \\
\text { Chinese medicine } \\
\text { Gao J., et al. study }\end{array}$ \\
\hline $500 \mathrm{mg} \mathrm{q} 12 \mathrm{~h}$ for 10 days & $\begin{array}{l}\text { Multicenter collaboration group of the department of sciences and } \\
\text { technology and Health commission of Guangdong province } \\
\text { Thai department of disease control } \\
\text { Italian society of infectious and tropical disease (Lombardy section) } \\
\text { Huang M., et al. study }\end{array}$ \\
\hline $\begin{array}{l}500 \mathrm{mg} \mathrm{q} 12 \mathrm{~h} \text { on day } 1-2 \\
\text { then } 500 \mathrm{mg} \text { q } 24 \mathrm{~h} \text { on day } 3-7\end{array}$ & $\begin{array}{l}\text { National health commission and state of administration of traditional } \\
\text { Chinese medicine }\end{array}$ \\
\hline $\begin{array}{l}750 \mathrm{mg} \mathrm{q} 12 \mathrm{~h} \text { on day } 1 \\
\text { then } 750 \mathrm{mg} \mathrm{q} 24 \mathrm{~h} \text { on day } 2-5 \\
1,000 \mathrm{mg} \mathrm{q} 12 \mathrm{~h} \text { for } 10 \text { days }\end{array}$ & Borba M., et al. study \\
\hline $\begin{array}{l}1,000 \mathrm{mg} \mathrm{q} 24 \mathrm{~h} \text { on day } 1 \\
\text { then } 500 \mathrm{mg} \text { q } 24 \mathrm{~h} \text { on day } 2-7\end{array}$ & The U.S. food and drug administration (FDA) \\
\hline $\begin{array}{l}1,000 \mathrm{mg} \text { then } 500 \mathrm{mg} \text { after } 12 \mathrm{~h} \text { on day } 1 \text { then } \\
500 \mathrm{mg} \text { BID on day } 2-5\end{array}$ & Dutch center of disease control \\
\hline $\begin{array}{l}750 \mathrm{mg} \text { q6h on day } 1-2 \\
\text { then } 500 \mathrm{mg} \text { q12h on day } 3-10\end{array}$ & \multirow{4}{*}{ Our designed regimens } \\
\hline $\begin{array}{l}1,000 \mathrm{mg} \mathrm{q} 8 \mathrm{~h} \text { on day } 1-2 \text { then } \\
500 \mathrm{mg} \mathrm{q} 12 \mathrm{~h} \text { on day } 3-10\end{array}$ & \\
\hline $\begin{array}{l}500 \mathrm{mg} q 6 \mathrm{~h} \text { on day } 1-3 \text { then } \\
500 \mathrm{mg} \mathrm{q} 12 \mathrm{~h} \text { on day } 4-10\end{array}$ & \\
\hline $\begin{array}{l}750 \mathrm{mg} \mathrm{q} 8 \mathrm{~h} \text { on day } 1-3 \text { then } \\
500 \mathrm{mg} \mathrm{q} 12 \mathrm{~h} \text { on day } 4-10\end{array}$ & \\
\hline
\end{tabular}

\section{RESULTS}

Simulated whole blood CQ concentrationtime profiles for the previously proposed regimens in published guidelines, regimens used in clinical studies, and our designed regimens are shown in Figures 1 and 2. The PTA for the efficacy and toxicity of all simulated regimens are summarized in Table 3. Regarding the efficacy, besides the highest proposed dosage regimen of CQP $1,000 \mathrm{mg}$ every 12 hours for 10 days, the other previously proposed regimens could not achieve $\geq 90 \% \mathrm{PTA}_{\text {eff }}$ during the treatment course. The highest proposed dosage regimen has achieved $98.31 \% \mathrm{PTA}_{\text {eff }}$ since the fourth day and maintained above $90 \%$ afterward. The reference dosage regimen, CQP 500 mg every regimens, loading doses of CQP $750 \mathrm{mg}$ every 6 hours or $1000 \mathrm{mg}$ every 8 hours for two consecutive days, followed by maintenance doses of $500 \mathrm{mg}$ every 12 hours for 8 days, achieved almost $100 \%$ $\mathrm{PTA}_{\text {eff }}$ on the second day. Other designed regimens with lower loading doses of $500 \mathrm{mg}$ every 6 hours 


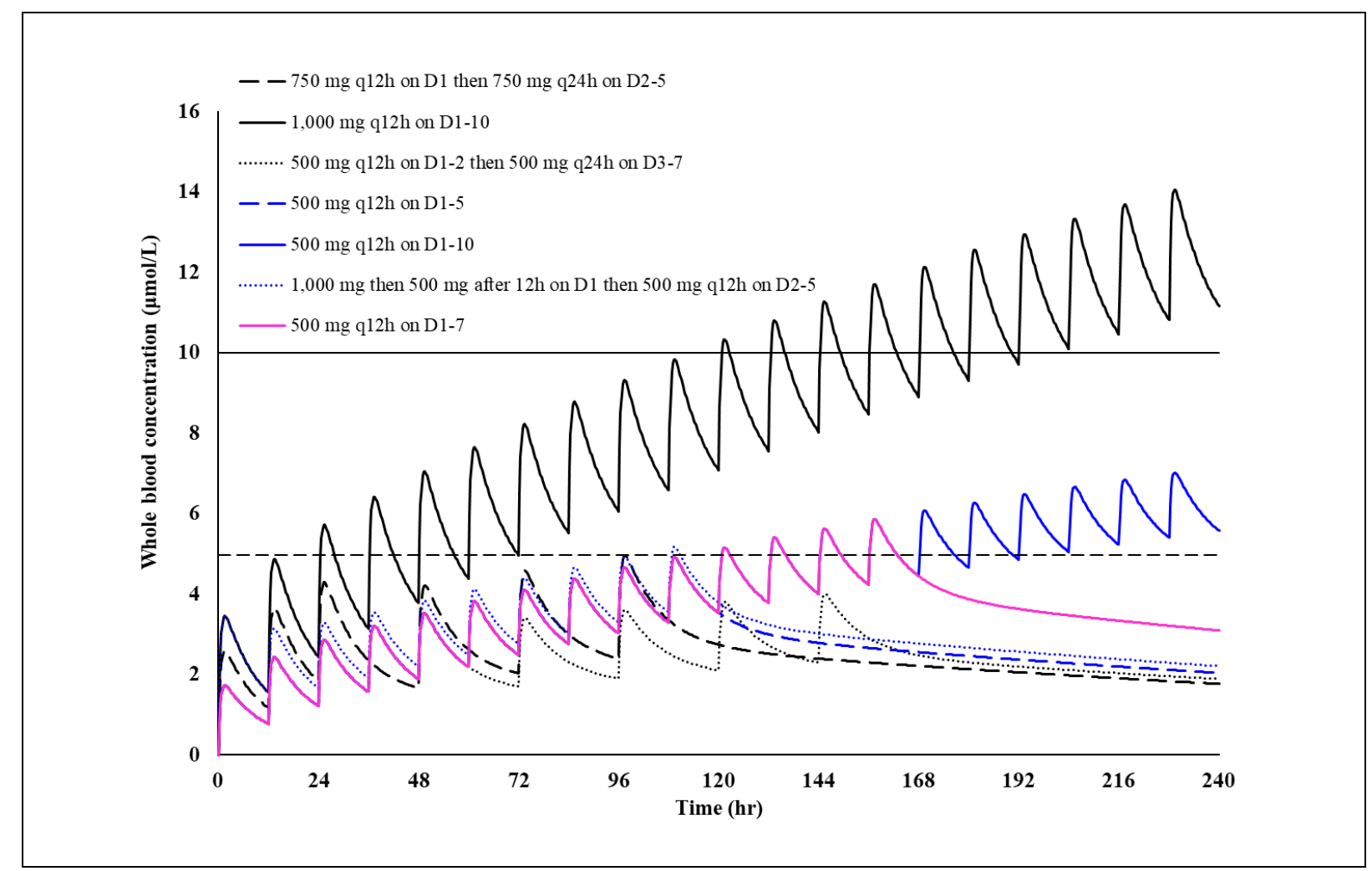

Figure 1. The whole blood chloroquine concentration time profile of the previously proposed regimens in published guidelines and clinical studies. Horizontal dash line indicates the minimum efficacious concentration $(4.98 \mu \mathrm{mol} / \mathrm{mL})$, and bold line indicates the maximum toxicity concentration $(10.00 \mu \mathrm{mol} / \mathrm{mL})$.

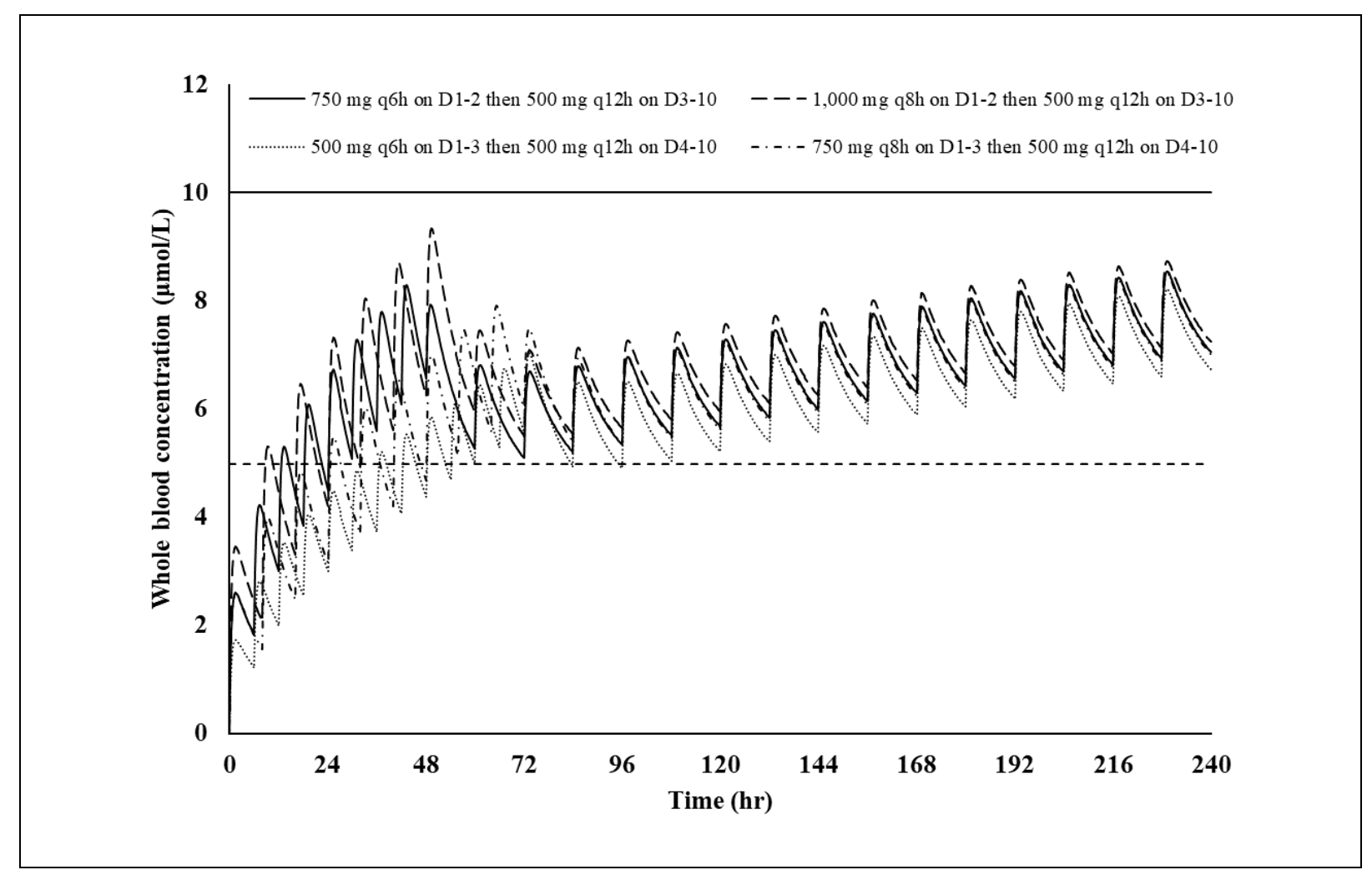

Figure 2. The whole blood chloroquine concentration time profile of our designed regimens. Horizontal dash line indicates the minimum efficacious concentration $(4.98 \mu \mathrm{mol} / \mathrm{mL})$, and bold line indicates the maximum toxicity concentration $(10.00 \mu \mathrm{mol} / \mathrm{mL})$. 
or $750 \mathrm{mg}$ every 8 hours for 3 consecutive days, followed by maintenance doses of $500 \mathrm{mg}$ every 12 hours for 7 days, achieved $\geq 90 \% \mathrm{PTA}_{\text {eff }}$ later on the third day.

In terms of toxicity, all previously proposed regimens had $\mathrm{PTA}_{\text {tox }}$ below $1 \%$ throughout the treatment course, except the regimen with CQP $1,000 \mathrm{mg}$ every 12 hours for 10 days, which yielded $\geq 1 \%$ PTA $_{\text {tox }}$ on the fourth day and increased continuously afterward. Focusing on our designed regimens, $\mathrm{PTA}_{\text {tox }}$ of at least $1 \%$ was observed only with the regimen with a loading dose of $1,000 \mathrm{mg}$ every 8 hours for 2 consecutive days, which attained $9.82 \%$ and $2.00 \%$ on the third and tenth day, respectively.

\section{DISCUSSION}

The number of patients infected with SARS-CoV-2 has been increasing worldwide. Although most of the patients were classified as a mild disease, approximately $15-20 \%$ were severe requiring admission to intensive care unit $(\mathrm{ICU})^{40-42}$. Previous clinical data suggested that severe COVID-19 patients had up to 60 times higher respiratory sample viral load than those with mild disease ${ }^{24,43,44}$. The viral load was higher during early and progressive phases compared to the recovery phase ${ }^{24}$, and its high viral load was associated with high infectivity in cell culture model $^{23}$, indicated that SARS-CoV-2 could be more easily transmittable during early admission. Front-line healthcare workers, who required close personal exposure, had at least 3-fold increased risk for SARS-CoV-2 infection compared to the general community ${ }^{20}$. The infection rate among this group was reported as high as $10-20 \%$ in several cross-sectional studies ${ }^{21,22}$. Since these data highlighted the importance of an early virological clearance, antiviral treatment in COVID-19 should rapidly achieve the PK/PD target, particularly in patients with severe disease, to prevent the transmission to front-line healthcare worker.

In our Monte Carlo simulations, we found that among the previously proposed dosage regimens, only the highest dosage regimen, CQP $1,000 \mathrm{mg}$ every 12 hours for 10 days, could achieve $\geq 90 \%$ PTA $A_{\text {eff }}$ during the treatment course (Table 3). This indicates that most of the regimens that have been used may not attain virological clearance, likely contributing to doubtful effectiveness of CQ. However, our result was inconsistent with the clinical study by Borba et al., which only $22.2 \%$ of CQ treated patients attained viral negative conversion on the fourth day. This discrepancy could be explained because they included only a small number of nasopharyngeal and/or oropharyngeal samples (27/81 patients; $33.33 \%)$. Moreover, these samples were collected from patients irrespective of their treated dosage regimens ${ }^{39}$. Thus, the reported conversion rate might not adequately represent the effectiveness of the highest dosage regimen. Regarding the toxicity, our simulation found that the highest proposed dosage regimen also reached above $1 \% \mathrm{PTA}_{\text {tox }}$ on the fourth day (Table 3). The PTA ${ }_{\text {tox }}$ on the fourth day of the highest proposed dosage regimen was $2.13 \%$, which was much lower than the incidence of prolonged QTc interval and ventricular tachycardia $(15 \%)$ reported in the clinical study ${ }^{39}$. This difference might be explained by the fact that most patients in the clinical study were concurrently treated with the known QTc prolonging agents, such as azithromycin, and oseltamivir, causing pharmacodynamic interactions with CQ and increased cardiac adverse events. Taken together, we admitted that more clinical studies are required to prove benefit of CQ on SARS-CoV-2 clearance. However, due to its extremely low PTA $\mathrm{Aff}_{\text {from }}$ our simulations, we suggested that all lower proposed dosage regimens besides CQP 1,000 mg every 12 hours, should not be used in further conducted clinical studies.

Focusing on potential benefit of an early virological clearance, we designed our regimens to achieved PK/PD target earlier within the first 48-72 hours. Our simulations suggested that large amount of loading dose was required for early achievement of efficacy target above $90 \%$. CQP regimens with a loading dose of at least $3 \mathrm{~g}$ per day for two consecutive days rapidly reach efficacy at 48 hours, while a loading dose of at least $2 \mathrm{~g}$ per day for 3 consecutive days reached the target later at 72 hours (Table 3 ). Although these loading doses were much higher than previously proposed regimens, several in vitro studies ${ }^{5,8}$ have unveiled the increase of inhibition percentage as the CQ concentration risen, indicated the concentration-dependent manner against SARS-CoV-2. Moreover, our pre-defined $\mathrm{PK} / \mathrm{PD}$ target was obtained from the clinical study ${ }^{19}$, which CQ treated patients had successful viral negative conversion. Therefore, early PK/PD target achievement with these high loading doses could early attain virological clearance. Regarding the toxicity, our simulations have unveiled the impact of dose frequently on the probability of toxicity. CQP regimens with a loading dose of $3 \mathrm{~g}$ per day, given $1000 \mathrm{mg}$ every $8 \mathrm{~h}$ for two consecutive days reached $2 \% \mathrm{PTA}_{\text {tox }}$ on the tenth day, while more 
Table 3. PTAs at targeted pharmacodynamic surrogate indices for efficacy $\left(\mathrm{C}_{\text {trough }} \geq 4.98 \mu \mathrm{mol} / \mathrm{mL}\right)$ and safety $\left(\mathrm{C}_{\text {peak }} \geq 10 \mu \mathrm{mol} / \mathrm{mL}\right)$ during the treatment course of CQ.

\begin{tabular}{|c|c|c|c|c|c|c|c|}
\hline \multirow{2}{*}{ CQ phosphate dosage regimens } & \multirow{2}{*}{ PTA $(\%)$} & \multicolumn{6}{|c|}{ Day of therapy } \\
\hline & & Day 2 & Day 3 & Day 4 & Day 5 & Day 7 & Day 10 \\
\hline \multicolumn{8}{|l|}{ Previously proposed regimens } \\
\hline \multirow{2}{*}{$500 \mathrm{mg} \mathrm{q} 12 \mathrm{~h}$ for 5 days } & PTA $_{\text {eff }}$ & 0.00 & 0.00 & 0.00 & 0.02 & 0.00 & 0.00 \\
\hline & PTA tox & 0.00 & 0.00 & 0.00 & 0.00 & 0.00 & 0.00 \\
\hline \multirow{2}{*}{$500 \mathrm{mg} \mathrm{q} 12 \mathrm{~h}$ for 7 days } & PTA $_{\text {eff }}$ & 0.00 & 0.00 & 0.01 & 0.03 & 13.52 & 0.00 \\
\hline & PTA tox & 0.00 & 0.00 & 0.00 & 0.00 & 0.29 & 0.00 \\
\hline \multirow{2}{*}{$500 \mathrm{mg} \mathrm{q} 12 \mathrm{~h}$ for 10 days } & PTA $_{\text {eff }}$ & 0.00 & 0.00 & 0.00 & 0.02 & 13.84 & 89.98 \\
\hline & PTAtox & 0.00 & 0.00 & 0.00 & 0.00 & 0.00 & 0.00 \\
\hline \multirow{2}{*}{$\begin{array}{l}500 \mathrm{mg} \mathrm{q} 12 \mathrm{~h} \text { on day } 1-2 \\
\text { then } 500 \mathrm{mg} \text { q } 24 \mathrm{~h} \text { on day } 3-7\end{array}$} & PTA $_{\text {eff }}$ & 0.00 & 0.00 & 0.00 & 0.00 & 0.00 & 0.00 \\
\hline & PTA tox & 0.00 & 0.00 & 0.00 & 0.00 & 0.00 & 0.00 \\
\hline \multirow{2}{*}{$\begin{array}{l}750 \mathrm{mg} \mathrm{q} 12 \mathrm{~h} \text { on day } 1 \\
\text { then } 750 \mathrm{mg} \text { q } 24 \mathrm{~h} \text { on day } 2-5\end{array}$} & PTA $_{\text {eff }}$ & 0.00 & 0.00 & 0.00 & 0.00 & 0.00 & 0.00 \\
\hline & PTA $_{\text {tox }}$ & 0.00 & 0.00 & 0.00 & 0.00 & 0.00 & 0.00 \\
\hline \multirow{2}{*}{$\begin{array}{l}1,000 \mathrm{mg} \mathrm{q} 24 \mathrm{~h} \text { on day } 1 \\
\text { then } 500 \mathrm{mg} \text { q } 24 \mathrm{~h} \text { on day } 2-7\end{array}$} & PTA $_{\text {eff }}$ & 0.00 & 0.00 & 0.00 & 0.00 & 0.00 & 0.00 \\
\hline & PTA $_{\text {tox }}$ & 0.00 & 0.00 & 0.00 & 0.00 & 0.00 & 0.00 \\
\hline \multirow{2}{*}{$1,000 \mathrm{mg} \mathrm{q} 12 \mathrm{~h}$ for 10 days } & PTA $_{\text {eff }}$ & 0.04 & 52.13 & 98.31 & 100.00 & 100.00 & 100.00 \\
\hline & PTA $_{\text {tox }}$ & 0.00 & 0.00 & 2.13 & 43.00 & 99.04 & 100.00 \\
\hline \multirow{2}{*}{$\begin{array}{l}1,000 \mathrm{mg} \text { then } 500 \mathrm{mg} \text { after } 12 \mathrm{~h} \text { on day } \\
1 \text { then } 500 \mathrm{mg} \mathrm{q} 12 \mathrm{~h} \text { on day } 2-5\end{array}$} & PTA $_{\text {eff }}$ & 0.00 & 0.00 & 0.00 & 0.18 & 0.00 & 0.00 \\
\hline & PTA $_{\text {tox }}$ & 0.00 & 0.00 & 0.00 & 0.00 & 0.00 & 0.00 \\
\hline \multicolumn{8}{|l|}{ Our designed regimens } \\
\hline \multirow{2}{*}{$\begin{array}{l}750 \mathrm{mg} q 6 \mathrm{~h} \text { on day } 1-2 \\
\text { then } 500 \mathrm{mg} \text { q } 12 \mathrm{~h} \text { on day } 3-10\end{array}$} & PTA $_{\text {eff }}$ & 100.00 & 61.95 & 76.66 & 90.16 & 98.91 & 99.98 \\
\hline & PTA $_{\text {tox }}$ & 0.00 & 0.00 & 0.00 & 0.00 & 0.01 & 0.66 \\
\hline \multirow{2}{*}{$\begin{array}{l}1,000 \mathrm{mg} \mathrm{q} 8 \mathrm{~h} \text { on day } 1-2 \\
\text { then } 500 \mathrm{mg} \text { q12h on day } 3-10\end{array}$} & PTA $_{\text {eff }}$ & 99.99 & 83.32 & 87.77 & 95.23 & 99.57 & 99.99 \\
\hline & PTA $_{\text {tox }}$ & 0.14 & 9.82 & 0.00 & 0.01 & 0.14 & 2.00 \\
\hline \multirow{2}{*}{$\begin{array}{l}500 \mathrm{mg} q 6 \mathrm{~h} \text { on day } 1-3 \\
\text { then } 500 \mathrm{mg} \text { q } 12 \mathrm{~h} \text { on day } 4-10\end{array}$} & PTA $_{\text {eff }}$ & 3.46 & 94.37 & 49.23 & 70.00 & 95.59 & 99.91 \\
\hline & PTA $_{\text {tox }}$ & 0.00 & 0.00 & 0.00 & 0.00 & 0.00 & 0.16 \\
\hline \multirow{2}{*}{$\begin{array}{l}750 \mathrm{mg} \mathrm{q} 8 \mathrm{~h} \text { on day } 1-3 \\
\text { then } 500 \mathrm{mg} \text { q } 12 \mathrm{~h} \text { on day } 4-10\end{array}$} & PTA $_{\text {eff }}$ & 21.11 & 99.21 & 76.35 & 88.44 & 98.51 & 99.99 \\
\hline & PTA $_{\text {tox }}$ & 0.00 & 0.01 & 0.00 & 0.00 & 0.02 & 0.68 \\
\hline
\end{tabular}

$\overline{P T A}$, probability of target attainment; $C_{\text {trough }}$ minimum chloroquine whole blood concentration; $C_{\text {peak }}$ maximum chloroquine whole blood concentration; CQ, chloroquine; PTA eff, PTA for efficacy; PTA tox, PTA for toxicity.

frequent regimens of $750 \mathrm{mg}$ every $6 \mathrm{~h}$ for two consecutive days had lower PTA tox at $0.66 \%$. Similarly, lower loading dose of $2 \mathrm{~g}$ per day, given $500 \mathrm{mg}$ every $6 \mathrm{~h}$ for 3 consecutive days, had even lower PTA tox at $0.16 \%$ on the tenth day (Table 3 ). These emphasized the finding from previous PK study that lower dosage each time resulted in lower peak blood concentration ${ }^{31}$, which consequently contributed to lower PTA $\mathrm{P}_{\text {tox. }}$ Thus, among the regimens with the same total amount of loading dose per day, the more frequent regimen appears to be more favorable.

Our simulations also suggested that regimens with high loading dose (2-3 g CQP per day) were likely safe, as shown by their low PTA $_{\text {tox }}$ (Table 3). The previous intentional CQ overdose study ${ }^{45}$ showed that the highest ingested dose that caused no clinical cardiac symptoms or severe EKG abnormality was $2.25 \mathrm{~g} \mathrm{CQ}$ base (3.75 g CQP). Likewise, the clinical study in COVID-19 by Borba et al. ${ }^{39}$ found that patients who developed QTc prolongation (QTc interval more than 500 milliseconds) and ventricular tachycardia (11/73 patients) had mean cumulated CQP dosage of approximately $3.5 \mathrm{~g}$. These adverse events occurred during the first four days of CQ treatment. Nevertheless, as discussed earlier, most patients were concurrently treated with known QTc prolonging agent. Also, the causation between cumulated CQ dosage and incidence of adverse events has not been evaluated. Our simulations using peak blood concentration as toxicity cutpoint, which highly correlated with mortality rate $^{28,46}$, might be more appropriate for assessing the safety of CQ dosage regimens. Therefore, our designed dosage regimens with high loading 
dose could be safe options for achieving early virological clearance in COVID-19. However, since these high dosage regimens have never been evaluated in the clinical study, patients should be closely monitored, particularly during the first four days of concurrent treatment with other known QTc prolonging agents.

In summary, since recent clinical studies confirmed that HCQ, a hydroxyl analogue of $\mathrm{CQ}$, showed no additional benefit on mortality reduction ${ }^{11-13}$ or improving clinical COVID status ${ }^{14-16}$ to usual care, CQ might consequently not secure the position as an antiviral treatment for COVID-19. Our simulations, therefore, did not intend to propose treatment regimens of CQ for COVID-19. However, its promising in vitro efficacy $6,8,9$ and viral clearance benefit in clinical trial ${ }^{19}$ emphasized the possible usage for early achievement of virological clearance. We therefore simulated regimens with high loading dose for early attainment of virological clearance to reduce in-hospital transmissions. Our designed dosage regimens might not be the best optimized regimens. However, they were based on the best available in vitro and clinical data. Further clinical studies are still required to prove viral clearance benefit and safety of our designed regimen.

Limitations of this study are as follows. 1) since our selected population PK study did not find any covariate in the final model $^{27}$, we did not evaluate the impact of important factors, such as body weight and renal or liver impairment on the whole blood concentration, 2) due to the lack of population PK studies in COVID-19, we assumed same physiologic properties between uncomplicated malaria and COVID-19 populations. Disease severity may affect the PK of the drug, especially in critically ill patient, which the alteration in volume of distribution and clearance may affect the drug concentration $^{47}, 3$ ) our pre-defined concentration targets were based on blood concentration. We did not simulate drug levels in the peripheral tissues. However, since preclinical data suggested that CQ concentration in lung tissue was much higher (11.8-450.0 times) than plasma ${ }^{48}$, adequate blood concentration would provide sufficient lung tissue concentration. Therefore, our results might be applicable to this site of infection, 4) we did not evaluate the effect of drug-drug interaction on either drug concentration or possible increased toxicities. The combination of known QT-prolonging agents should be careful considered, particularly in patient with underlying cardiac conditions or concurrently treated with possible CQ interacting agents.

\section{CONCLUSIONS}

Our study indicated that large amount of CQP loading dose might be necessary to attain early virological clearance within 48-72 hours. We also recommended regimen with loading doses of 500 mg every 6 hours for 3 consecutive days, followed by maintenance doses of $500 \mathrm{mg}$ every 12 hours for 7 days. However, this regimen should be further evaluated in clinical studies.

\section{ACKNOWLEDGMENTS}

The authors thank Asst. Prof. Dr. Thitima Wattanavijitkul, Faculty of Pharmaceutical Sciences, Chulalongkorn University for her valuable comments and suggestions.

\section{Conflict of interest}

The authors declare no conflict of interest.

\section{Funding}

This study received no external funding.

\section{Ethics approval}

This study was approved by the Institutional Review Board of Faculty of Dentistry/Faculty of Pharmacy, Mahidol University (COE.No.MUDT/PY-IRB 2020/026.0807).

\section{Article info:}

Received December 31, 2020

Received in revised form February 19, 2021

Accepted February 23, 2021

\section{REFERENCES}

1. Sohrabi C, Alsafi Z, O'Neill N, Khan M, Kerwan A, AlJabir A, et al. World Health Organization declares global emergency: A review of the 2019 novel coronavirus (COVID-19). Int J Surg. 2020;76:71-6.

2. National Institute of Health. antiviral therapy-coronavirus disease COVID-19 [document on the internet]; 2020 [cited 2020 Aug 24]. Available from: https://www.covid19 treatmentguidelines.nih.gov/antiviral-therapy/.

3. Infectious Diseases Soceity of America. Infectious Diseases Society of America guidelines on the treatment and management of patients with COVID-19 [document on the internet]; 2020 [cited 2020 Aug 24]. Available from: https://www.idsociety.org/practice-guideline/covid-19guideline-treatment-and-management/\#toc-3.

4. Department of Disease Control. Treatment guidelines for COVID-19 [document on the internet]; 2020 [cited 2020 Aug 24]. Available from: https://ddc.moph.go.th/ viralpneumonia/eng/file/guidelines/g_treatment.pdf.

5. Wang M, Cao R, Zhang L, Yang X, Liu J, Xu M, et al. Remdesivir and chloroquine effectively inhibit the recently emerged novel coronavirus $(2019-\mathrm{nCoV})$ in vitro. Cell Res. 2020;30(3):269-71.

6. Wang Y, Zhang D, Du G, Du R, Zhao J, Jin Y, et al. Remdesivir in adults with severe COVID-19: A randomised, double-blind, placebo-controlled, multicentre trial. Lancet. 2020;395(10236):1569-78. 
7. Beigel JH, Tomashek KM, Dodd LE, Mehta AK, Zingman BS, Kalil AC, et al. Remdesivir for the treatment of Covid-19 - Final Report. N Engl J Med. 2020;383(19):1813-26.

8. Liu J, Cao R, Xu M, Wang X, Zhang H, Hu H, et al. Hydroxychloroquine, a less toxic derivative of chloroquine, is effective in inhibiting SARS-CoV-2 infection in vitro. Cell Discov. 2020;6:16.

9. Yao X, Ye F, Zhang M, Cui C, Huang B, Niu P, et al. In vitro antiviral activity and projection of optimized dosing design of hydroxychloroquine for the treatment of severe acute respiratory syndrome coronavirus 2 (SARS-CoV-2). Clin Infect Dis. 2020;71(15):732-9.

10. Gao J, Tian Z, Yang X. Breakthrough: Chloroquine phosphate has shown apparent efficacy in treatment of COVID-19 associated pneumonia in clinical studies. Biosci Trends. 2020;14(1):72-3.

11. Abd-Elsalam S, Esmail ES, Khalaf M, Abdo EF, Medhat MA, Abd El Ghafar MS, et al. Hydroxychloroquine in the treatment of COVID-19: A multicenter randomized controlled study. Am J Trop Med Hyg. 2020;103(4):1635-9.

12. Horby P, Mafham M, Linsell L, Bell JL, Staplin N, Emberson JR, et al. Effect of hydroxychloroquine in hospitalized patients with Covid-19. N Engl J Med. 2020;383(21):2030-40.

13. Pan H, Peto R, Henao-Restrepo AM, Preziosi MP, Sathiyamoorthy V, Abdool Karim Q, et al. Repurposed antiviral drugs for COVID-19 - interim WHO solidarity trial results. N Engl J Med. 2021;384(6):497-511.

14. Skipper CP, Pastick KA, Engen NW, Bangdiwala AS, Abassi M, Lofgren SM, et al. Hydroxychloroquine in nonhospitalized adults with early COVID-19: A randomized trial. Ann Intern Med. 2020;173(8):623-31.

15. Self WH, Semler MW, Leither LM, Casey JD, Angus DC, Brower RG, et al. Effect of hydroxychloroquine on clinical status at 14 days in hospitalized patients with COVID-19: A randomized clinical trial. JAMA. 2020; 324(21):2165-76.

16. Cavalcanti AB, Zampieri FG, Rosa RG, Azevedo LCP, Veiga VC, Avezum A, et al. Hydroxychloroquine with or without azithromycin in mild-to-moderate COVID-19. N Engl J Med. 2020;383(21):2041-52.

17. The United States Food and Drug Administration. Letter revoking EUA for chloroquine phosphate and hydroxylchloroquine sulfate [document on the internet]; 2020 [cited 2020 Aug 24]. Available from: https://www.fda. gov/media/138945/download

18. Tang W, Cao Z, Han M, Wang Z, Chen J, Sun W, et al. Hydroxychloroquine in patients with mainly mild to moderate coronavirus disease 2019: Open label, randomised controlled trial. BMJ. 2020;369:m1849.

19. Huang M, Tang T, Pang P, Li M, Ma R, Lu J, et al. Treating COVID-19 with chloroquine. J Mol Cell Biol. 2020;12(4):322-5.

20. Nguyen LH, Drew DA, Graham MS, Joshi AD, Guo C$\mathrm{G}, \mathrm{Ma} \mathrm{W}$, et al. Risk of COVID-19 among front-line health-care workers and the general community: A prospective cohort study. The Lancet Public Health. 2020;5(9):e475-83.

21. Lazzerini M, Putoto G. COVID-19 in Italy: Momentous decisions and many uncertainties. Lancet Glob Health. 2020;8(5):e641-2.

22. CDC COVID-19 Response Team. Characteristics of health care personnel with COVID-19 - United States, February 12-April 9, 2020. MMWR Morb Mortal Wkly Rep. 2020;69(15):477-81.
23. La Scola B, Le Bideau M, Andreani J, Hoang VT, Grimaldier C, Colson P, et al. Viral RNA load as determined by cell culture as a management tool for discharge of SARS-CoV-2 patients from infectious disease wards. Eur J Clin Microbiol Infect Dis. 2020; 39(6):1059-61.

24. Yu X, Sun S, Shi Y, Wang H, Zhao R, Sheng J. SARSCoV-2 viral load in sputum correlates with risk of COVID-19 progression. Crit Care. 2020;24(1):170.

25. Bonate PL. A brief introduction to Monte Carlo simulation. Clin Pharmacokinet. 2001;40(1):15-22.

26. Roberts JA, Kirkpatrick CM, Lipman J. Monte Carlo simulations: Maximizing antibiotic pharmacokinetic data to optimize clinical practice for critically ill patients. J Antimicrob Chemother. 2011;66(2):227-31.

27. Hoglund R, Moussavi Y, Ruengweerayut R, Cheomung A, Abelo A, Na-Bangchang K. Population pharmacokinetics of a three-day chloroquine treatment in patients with Plasmodium vivax infection on the Thai-Myanmar border. Malar J. 2016;15:129.

28. Watson JA, Tarning J, Hoglund RM, Baud FJ, Megarbane B, Clemessy JL, et al. Concentrationdependent mortality of chloroquine in overdose. Elife. 2020;9:e58631.

29. Frisk-Holmberg M, Bergkvist Y, Domeij-Nyberg B, Hellstrom L, Jansson F. Chloroquine serum concentration and side effects: Evidence for dose-dependent kinetics. Clin Pharmacol Ther. 1979;25(3):345-50.

30. Cui C, Zhang M, Yao X, Tu S, Hou Z, Jie En VS, et al. Dose selection of chloroquine phosphate for treatment of COVID-19 based on a physiologically based pharmacokinetic model. Acta Pharmaceutica Sinica B. 2020; 10(7):1216-27.

31. Karalis V, Ismailos G, Karatza E. Chloroquine dosage regimens in patients with COVID-19: Safety risks and optimization using simulations. Safety Sci. 2020;129: 104842

32. Riou B, Barriot P, Rimailho A, Baud FJ. Treatment of severe chloroquine poisoning. NEngl J Med. 1988;318(1):1-6.

33. Gustafsson LL, Rombo L, Alván G, Björkman A, Lind $\mathrm{M}$, Walker $\mathrm{O}$. On the question of dose-dependent chloroquine elimination of a single oral dose. Clin Pharmacol Ther. 1983;34(3):383-5.

34. Multicenter Collaboration Group of Department of Science and Technology of Guangdong Province and Health Commission of Guangdong Province for Chloroquine in the Treatment of Novel Coronavirus Pneumonia. [Expert consensus on chloroquine phosphate for the treatment of novel coronavirus pneumonia]. Zhonghua Jie He He Hu Xi Za Zhi. 2020;43(3):185-8.

35. The United States Food and Drug Administration. Fact sheet for health care providers' emergency use of authorization (EUA) of chloroquine phosphate suppled from the strategic national stockpile for treatment of COVID-19 in certain hospitalized patients [document on the internet]; 2020 [cited 2020 May 4]. Available from: https://www.fda.gov/media/136535/download.

36. National Health Commision \& State Administration of Traditional Chinese Medicine. Diagnosis and treatment protocol for novel coronavirus pneumonia (Trial version 7). 2020 Mar 3 [document on the internet]; 2020 [cited 2020 May 4]. Available from: https://www.chinadaily. com.cn/pdf/2020/1.Clinical.Protocols.for.the.Diagnosis .and.Treatment.of.COVID-19.V7.pdf.

37. Rijksinstituut voor Volksgezondheid en Milieu. Medicamenteuze behandelopties bij patiënten met COVID-19 (infecties met SARS-CoV-2) [document on the internet]; 
2020 [cited 2020 May 4]. Available from: https://lci.rivm.nl/ covid-19/bijlage/behandeladvies.

38. Società Italiana di Malattie Infettive e Tropicali. Linee guida sulla gestione terapeutica e di supportoper pazienti con infezioneda coronavirus COVID-19 [document on the internet]; 2020 [cited 2020 May 4]. Available from: http://www.simit.org/medias/1555-covid19-linee-guidatrattamento-01mar.pdf.

39. Borba MGS, Val FFA, Sampaio VS, Alexandre MAA, Melo GC, Brito M, et al. Effect of high vs low doses of chloroquine diphosphate as adjunctive therapy for patients hospitalized with severe acute respiratory syndrome coronavirus 2 (SARS-CoV-2) infection: A randomized clinical trial. JAMA Network Open. 2020;3(4):e208857.

40. Docherty AB, Harrison EM, Green CA, Hardwick HE, Pius R, Norman L, et al. Features of 20133 UK patients in hospital with COVID-19 using the ISARIC WHO Clinical Characterisation Protocol: prospective observational cohort study. BMJ. 2020;369:m1985.

41. Richardson S, Hirsch JS, Narasimhan M, Crawford JM, McGinn T, Davidson KW, et al. Presenting characteristics, comorbidities, and outcomes among 5700 patients hospitalized with COVID-19 in the New York City area. JAMA. 2020;323(20):2052-9.

42. Wu Z, McGoogan JM. Characteristics of and important lessons from the coronavirus disease 2019 (COVID-19) outbreak in China: Summary of a report of 72314 cases from the Chinese Center for Disease Control and Prevention. JAMA. 2020;323(13):1239-42.

43. Liu Y, Yan LM, Wan L, Xiang TX, Le A, Liu JM, et al. Viral dynamics in mild and severe cases of COVID-19. Lancet Infect Dis. 2020;20(6):656-7.

44. Zheng S, Fan J, Yu F, Feng B, Lou B, Zou Q, et al. Viral load dynamics and disease severity in patients infected with SARS-CoV-2 in Zhejiang province, China, JanuaryMarch 2020: Retrospective cohort study. BMJ. 2020; 369:m1443.

45. Britton WJ, Kevau IH. Intentional chloroquine overdosage. Med J Aust. 1978;2(9):407-10.

46. Clemessy JL, Taboulet P, Hoffman JR, Hantson P, Barriot $\mathrm{P}$, Bismuth $\mathrm{C}$, et al. Treatment of acute chloroquine poisoning: A 5-year experience. Crit Care Med. 1996;24(7): 1189-95.

47. Scaglione F, Paraboni L. Pharmacokinetics/pharmacodynamics of antibacterials in the Intensive Care Unit: Setting appropriate dosing regimens. Int J Antimicrob Agents. 2008;32(4):294-301

48. Adelusi SA, Salako LA. Kinetics of the distribution and elimination of chloroquine in the rat. Gen Pharmacol. 1982; 13(5):433-7. 